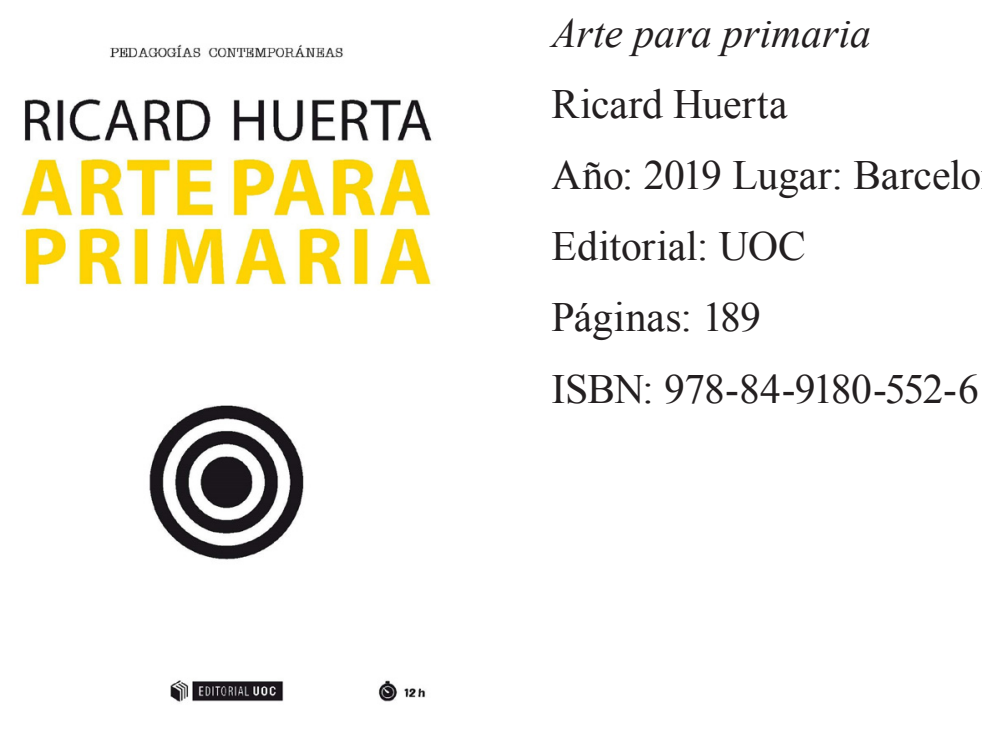

\title{
Educación a través del arte en Primaria: una necesidad
}

El libro de Arte para Primaria es un entramado de reflexiones, propuestas prácticas, argumentaciones y consejos para que el profesorado de primaria logre educar a través del arte. Ricard Huerta, Catedrático de Educación Artística de la Universitat de València y director del Grupo CREARI de Investigación en Pedagogías Culturales, nos muestra sus propuestas didácticas a través de la creación de entornos culturales innovadores desde un prisma pluridiverso, propiciando reflexiones éticas, estéticas, y por supuesto educativas. Además, nos sitúa en un panorama rizomático haciendo referencia a los flujos cambiantes del momento actual. Referencia las tendencias actuales, proponiendo un respeto hacia lo histórico, acercándose a un panorama visual de nuevas realidades.

Nos ejemplifica nuevas posiciones de lo corporal. Iniciativas basadas en la inclusión, el respeto y la coherencia académica. El respeto y el reconocimiento de la diversidad es algo que urge asumir y defender. Nos plantea también la importancia de que existan condiciones favorables para la apropiación social de la tecnología.

Durante todo el libro Ricard Huerta presta atención a lo que miramos y a cómo se mira, es decir, a cómo se conforman nuestras miradas sobre nosotros y nosotras y sobre el mundo. Propone incorporar al currículum de primaria, como eje clave de la actualización docente, cuestiones relativas a la diversidad sexual para concienciar al alumnado. Además, no olvida promover la lucha por la especialidad de educación artística en primaria, y cuestiona la preparación del profesorado que imparte la educación plástica en inglés en la educación primaria.

El autor nos muestra a modo de grandes trazos lo importante que es el trabajo con las imágenes, relatos digitales, autorretratos,... que ayudan a evocar y formular significados. Nos propone observar, reflexionar y hacer análisis de anuncios de 
publicidad para resolver la necesidad de convivir ecológicamente con lo visual. La juventud se ha acostumbrado a la profusión de información, rizomas y derivas en línea, aconsejando a que los que nos dedicamos a la educación que la analicemos, para que el alumnado sea consciente tanto como ser individual, como social. Huerta nos marca las pautas de la selección de artistas, integrando los intereses del alumnado, para descubrir y disfrutar descubriendo. Introduce el concepto novedoso de curriculum vibrante, una apuesta para llevar el currículum hacia posiciones más atrevidas y porosas, mediante un escenario abierto que supere el corsé tradicional del ámbito curricular.

Ricard Huerta es partidario de una educación más humanizada, lúdica y placentera ligada a la realidad educativa. Cree en una educación comprometida en el arte, capaz de reaccionar, de reconectarse a nuestra realidad. Difumina las fronteras entre las materias usándola en pro de la motivación. Reflexiona sobre como la combinación entre narrativas orales con las imágenes permiten acercarnos a las realidades individuales. El poder de los alfabetos como argumento para enlazar lo político, lo educativo y lo visual. El cine como puerta abierta a las ideas y los comportamientos donde se contempla la diversidad. En definitiva, nos plantea herramientas para impulsar actitudes respetuosas y potenciar valores de convivencia. Desde las artes, el autor nos ofrece las claves para educar en la diversidad y hacer la disidencia más visible, los derechos humanos y la diversidad sexual. Además, nos muestra cómo el arte es una forma de rebelión contra las injusticias, de modo creativo y sugerente.

Según palabras del autor, la cultura visual y el arte contemporáneo están provocando cuestionamientos y reflexiones de las representaciones visuales, nuevas problemáticas que resultan influyentes en la construcción de las identidades del alumnado. Hace falta la alfabetización digital desde la perspectiva de lo visual y de la conciencia identitaria. Nos invita a desarrollar una mirada sensible, reflexiva, creativa, crítica y política sobre la realidad cultural diversa, lanzando el reto al profesorado de una idea transformadora y animándolo a construir nuevas visiones del mundo para transformar la realidad vivida. Confiando en la capacidad del profesorado para moldear nuevos recursos artísticos, pero recapacita sobre la necesidad de ofrecer al colectivo docente las herramientas adecuadas.

Arte para primaria ofrece nuevas estrategias para involucrar al profesorado en la práctica y el deleite de las artes desde la perspectiva de la educación. Tal y como ha evolucionado en los últimos años el floreciente sector de las artes, considera que ahora es el momento de atender las exigencias de la educación artística, con el fin de favorecer la participación y el disfrute. Se introducen conceptos novedosos como el de «currículum vibrante», una apuesta para llevar el currículum hacia posiciones más atrevidas y porosas, mediante un escenario abierto que supere el corsé tradicional del ámbito curricular. 